\title{
EVOLUTIONARY TRENDS IN THERMAL METABOLIC ACCLIMATION PATTERNS IN NORTHERN AND SOUTHERN HEMISPHERE CRUSTACEANS
}

\author{
F. JOHN VERNBERG and W. B. VERNBERG \\ Belle W. Baruch Coastal Research Institute and Bio- \\ logy Department University of South Carolina, Colum- \\ bia, South Carolina
} TENDENCIAS EVOLUCIONÁRIAS NOS TIPOS DE ACLIMATAÇÃO TERMICA
METABÓLICA EM CRUSTÁCEOS DOS HEMISFERIOS NORTE E SUL

\begin{abstract}
SUMĀRIO
Estudos foram conduzidos em caranguejos e copépodes pertencentes à mesma espécie ou espécies relacionadas dos hemisférios norte e sul, para determinar se estas espécies desenvolveram os mesmos tipos de resposta fisiológica em relação à temperatura nos extremos de sua distribuição geográfica nos dois hemisférios, ou se ao invés diferentes estratégias funcionais foram desenvolvidàs. Diferenças significantes foram notadas nos tipos de respostas fisiológicas tanto dos caranguejos como nos copépodes dos dois diferentes hemisférios. Ainda não se sabe se essas diferenças nas duas populaçōes refletem ou não diferenças genéticas; entretanto, estudos comparativos posteriores deverão fornecer os dados necessários para explicar adequadamente a diversidade fisiológica em populações geograficamente separadas.
\end{abstract}

\section{SUMMARY}

Studies were made of the same or closely related species of fiddler crabs and copepods common to both the northern and southern hemispheres in order to determine whether these species evolved the same physiological response patterns to temperature at both extremes of their geographical range in the two hemispheres, or if instead different functional strategies have evolved. Significant differences were noted in the physiological response patterns of both the copepod and fiddler crab species examined from the two different hemispheres. Still unanswered is the' 'question of whether or not the observed differences in the two populations reflect genetic differences; however, further comparative studies of this nature should provide the data necessary to adequately explain physiological diversity in geographically separated populations of organisms.

Número especial em homenagem ao Prof. Dr. Paulo Sawaya, no ano jubilar de seu magistério. 
Many years ago, Davenport (1897) questioned how some animals were able to survive in high temperature environments while others cannot, when he asked, "How has that acclimatization been effected?" This question has yet to be resolved, for the nature of the physiological mechanisms that enable organisms to survive in such diverse habitats as tropical and polar regions is still incompletely known. Every habitat has a distinctive set of environmental parameters, and populations of organisms living in these diverse habitats are exposed to different evolutionary selective factors. Therefore, it is not surprising that comparisons of organisms from divergent habitats indicate that different physiological responses to environmental stresses have evolved. For example, "heat" death of polar fish occurs at temperatures which cause "cold" death of tropical animals. Although many of the marked physiological variations between widely separated populations of organisms reflect genetic differences, some of the reported differences are examples of non-genetic acclimatization phenomenon (Vernberg, 1962; Vernberg and Vernberg, 1972).

Nature has provided biologists with some natural experimental areas for the study of physiological mechanisms involved in climatic adaptation. One such experimental area is the east coast of South and North America, especially the regions of the United States of Brazil and the United States of America. Numerous marine species, either the same or closely related species, are common to each country (Abbott, 1968; Pratt, 1948; Vanzolini, 1964; and Williams, 1965). Furthermore a similar thermal gradient extends both southward and

northward from the thermal equator which bisects Brazil. As a result, organisms in the south temperate and north temperate zones are exposed to similar seasonal fluctuations, yet are isolated from one another. Since many of these species are thought to have originated in the tropics and subsequently spread toward the poles, different adaptive mechanisms may have evolved in these widely separated populations. Although some studies which are discussed later have been published, there is a fertile field of physiological biogeographical research which has scarcely been touched. The present cooperative efforts of the University of São Paulo and the University of South Carolina represent a beginning on attacking this evolutionary problem. Studies on two groups of animals, fiddler crabs and copepods will illustrate some of the ongoing research involving Brazilian and United States of America species. 
This paper is dedicated to Dr. Paulo Sawaya who has greatly stimulated our interest in these studies and who has assisted in so many ways in promoting cooperative studies between Brazil and the United States of America.

Fiddler crabs, genus $U c a$, appear to have originated in the tropics, and subsequently migrated into both the southern and northern hemispheres. Of interest to evolutionary biologists is to determine whether the same species of crabs, or closely related species, evolved the same physiological response patterns to temperature at both extremes of their geographical range in the northern and southern hemispheres, or if instead different functional strategies have evolved. A number of studies show that animals from colder, higher latitudes tend to have higher metabolic rates than do animals from warmer, lower latitudes when measured at a comparable temperature. However, most of these studies have been confined to the northern hemispheres.

Thermal metabolic acclimation patterns were determined in populations of Uca rapax from Florida, Puerto Rico, Jamaica in the northern hemisphere and from Salvador, Bahia and Santos, São Paulo in Brazil and on a closely related species, $U$. pugnax, from North Carolina (Vermberg and Vernberg, 1966). The patterns of acclimation are distinctive for each population, but perhaps the most striking differences are found between the tropical zone species in the northern and southern hemispheres. Crabs of a single species, $U$. rapax, from Puerto Rico and Jamaica (Latitude $19 \mathrm{~N}$ ) and from Salvador, Bahia (Latitude $13 \mathrm{~S}$ ) not only experience very similar thermal environments, but also, at both of these latitudes, the temperature is relatively warm and constant throughout the year. However, the thermal metabolic acclimation patterns of the populations from Jamaica and Puerto Rico are very different from those of the populations from Salvador. The thermal acclimation pattern for whole animals from Jamaica is the classical picture, i.e., cold-acclimated animals have a significantly higher metabolic rate than warm-acclimated animals at comparable temperatures. In animals from Salvador, Bahia, however, this pattern was reversed. In this population the warm-acclimated animals had a higher metabolic rate than did the cold-acclimated animals. Other indices of physiological diversity were found. The $Q_{10}$ curves of warmacclimated animals from Jamaica and Salvador were very different. The time response of thermal acclimation in the two populations were also quite distinctive. Animals from Jamaica which were acclimated 
at $15^{\circ} \mathrm{C}$ for one day, then the metabolic rate determined at $25^{\circ} \mathrm{C}$, first showed a marked overshoot response followed by a gradual decrease to a lower constant level. Animals from Salvador treated in the same manner showed first a marked undershoot in metabolic rate followed by an increase in $\mathrm{Qo}_{2}$ to a constant level.

The absolute metabolic rates were also significantly different. Crabs in the northern hemisphere from Jamaica, Puerto Rico, Florida and North Carolina all had significantly lower metabolic rates at comparable temperatures than did crabs in the southern hemispheres. This same response has been reported for mussels from Brazil and Europe (Bayne, personal communication).

The thermal metabolic patterns of tissues of crabs are also distinctive for each population. The supraoesophageal ganglion (SEG) showed acclimation at different temperature levels: $U$. pugnax, from North Carolina acclimated only at high temperatures, $U$. rapax from Puerto Rico acclimated at high and intermediate temperatures, but this tissue from $U$. rapax from Salvador and Santos showed acclimation only at low temperature. Neither the SEG of crabs from the temperate zone (North Carolina) nor the subtropical zone (Santos) showed any change in $Q_{1}$ pattern with cold acclimation. There was a change in $Q_{10}$ pattern with cold acclimation in the SEG of the two tropical zone species. However, the peak of high $Q_{10}$ activity of the SEG from Salvador was not in the same position as the peak of high $Q_{10}$ acitivity in the SEG of crabs from Puerto Rico.

The metabolic acclimation patterns of muscle tissue of crabs from Puerto Rico showed acclimation at both high and low temperatures. The acclimation curve of this tissue from crabs from Salvador showed no acclimation to low temperatures, only to high temperatures. With cold-acclimation the peaks of high $\mathrm{Q}_{10}$ activity were to the left in more southerly distributed populations.

In all of these studies the experimental conditions were as nearly identical as was possible and the various variables were taken into consideration. The size factor was recognized and in whole animal studies the results are based on linear regressions; thus size as a factor is negated. Animals used in the tissue studies were of a very limited size range (1.4-2.3 cm carapace width), and only males were used in the experiments. The marked differences in metabolic response to thermal acclimation at both the tissue and whole animal 
level would indicate, then, that widely separated populations of fiddler crabs have evolved different physiological mechanisms in response to thermal changes.

The copepod Euterpina acutifrons offers another example of physiological diversity between northern and southern hemisphere species. Thermal metabolic acclimation patterns were determined for two populations of $E$. acutifrons, one from São Sebastião Channel, São Sebastião, Brazil, and the other from North Inlet Estuary near Georgetown, South Carolina (Moreira and Vernberg, 1968; Vernberg, 1972; and Vernberg and Moreira, 1973). In E. acutifrons, the males are dimorphic, one being noticeably smaller than the other in addition to having distinct morphological differences in antennules, antennae and second pair of legs. Studies were made on small males and non-gravid females from the two populations. The genotypic limits of metabolic response in these organisms was plotted by using data on oxygen consumption rates of cold- and warm-acclimated copepods. In both small males and non-gravid females, the Brazilian population showed markedly greater lability at high temperatures than did the South Carolina population. Conversely, the South Carolina population showed greatest lability at lower temperature. Such responses can be correlated with the thermal regime each population encounters in nature: the temperature range in São Sebastião Channel is from $20-31^{\circ} \mathrm{C}$, in North Inlet Estuary $12-28^{\circ} \mathrm{C}$; when temperatures drop below approximately $12^{\circ} \mathrm{C}$ in North Inlet, $E$. acutifrons disappears from the water column. Another striking difference between the two populations was the much higher rate of oxygen consumption observed in the northern hemisphere animals. This is in contrast to the results with fiddler crabs where the metabolic rates of southern hemisphere species were higher than those of northern hemisphere ones.

The question of whether or not the observed differences in the two populations reflect true genetic differences or not remains as yet unanswered.

Although the previous examples are restricted to fiddler crabs and copepods, the numerous other groups of organisms which have affinities to both Brazil and the U.S.A. need study. Comprehensive, integrated investigations involving a coordinated team of scientists from both countries are needed to provide the necessary data to adequately explain physiological diversity in geographically separated populations of organisms. 


\section{LITERATURE CITED}

ABBoTT, R. T. (1968) — Seashells of North America. Golden Press. New York.

DAVENPORT, C. B. (1897) - Experimental Morphology. Vol. 1. Macmillan Publishing Company. London and New York.

MOREIRA, G. S. and W. B. VERNBERG (1968) - Comparative thermal metabolic patterns in Euterpina acutifrons dimorphic males. Marine Biology, 1: 282-284.

PRATT, H. S. (1948) - A Manual of the Common Invertebrate Animals. Blakiston Company. Philadelphia and Toronto.

VANZOLINI, P E. (1964) - História Natural de Organismos Aquáticos do Brasil. Fundação de Amparo à Pesquisa do Estado de São Paulo. São Paulo.

VERNBERG, F. J. (1962) - Latitudinal effects on physiological properties of animal populations. A. Rev. Physiol. 24:517-546.

VERNBERG, F. J. and W. B. VERNBERG (1966) - Studies on the physiological variation between tropical and temperate zone fiddler crabs of the genus Uca. VII. Metabolic-temperature acclimation responses in southern hemisphere crabs. Comp. Biochem. Physiol., 19:489-524.

VERNBERG, W. B. (1972) - Metabolic-environmental interaction in marine plankton. Fifth European Marine Biology Symposium. Ed. B. Battaglia. pp. 189-196. Piccin Editore. Padova, Italy.

VERNBERG, W. B. and G. S. MOREIRA (1973) - Metabolic-Temperature responses of the copepod Euterpina acutifrons (Dana) from Brazil (In press).

VERNBERG, W. B. and F. J. VERNBERG (1972) - Environmental Physiology of Marine Animals. Springer-Verlag. New York, Heidelberg and Berlin.

WILliAMS, A. B. (1965) - Marine Decapod Crustaceans of the Carolina. Fishery Bulletin, 65:1-298. 